\title{
GAMBARAN KEKUATAN OTOT PADA LANSIA DI ROJINHOME YOICHI KOKUBA YONABARU OKINAWA JEPANG
}

\author{
Etika Dewi Cahyaningrum ${ }^{1}$, Nur Musyabiroh ${ }^{2}$ \\ ${ }^{1}$ Universitas Harapan Bangsa, \\ ${ }^{2}$ Universitas Harapan Bangsa, \\ *e-mail: tita.etika@gmail.com
}

\begin{tabular}{|c|c|}
\hline & Abstract \\
\hline $\begin{array}{l}\text { Keywords: } \\
\text { Gambaran } \\
\text { Kekuatan Otot, } \\
\text { Lansia, Range of } \\
\text { Motion. }\end{array}$ & $\begin{array}{l}\text { Lanjut usia merupakan seseorang yang telah memasuki usia } 60 \text { tahun ke } \\
\text { atas dan dapat disebut juga sebagai tahap lanjut dari suatu proses } \\
\text { kehidupan yang akan di alami oleh setiap individu. Kekuatan otot mulai } \\
\text { timbul sejak lahir sampai dewasa dan terus meningkat terutama pada } \\
\text { usia } 20 \text { sampai } 30 \text {-an dan secara gradual menurun seiring dengan } \\
\text { peningkatan usia. Perubahan morfologis pada fungsi muskuloskeletal } \\
\text { menjadi salah satu faktor pentingnya mengetahui gambaran kekuatan } \\
\text { otot. Penelitian ini bertujuan untuk mengetahui gambaran kekuatan otot } \\
\text { pada lansia di Rojinhome Yoichi Kokuba Yonabaru Okinawa Jepang. } \\
\text { Jenis penelitian yang digunakan adalah deskriptif kuantitatif. Teknik } \\
\text { sampling menggunakan teknik non probability sampling dengan jenis } \\
\text { quota sampling sebanyak } 20 \text { lansia. Data diambil dengan teknik } \\
\text { wawancara, data primer seperti data demografi responden, dan } \\
\text { pengukuran kekuatan otot dengan skala Medical Research Council } \\
\text { Muscle Scale. Hasil penelitian menunjukan sebagian besar responden } \\
\text { pada kategori lanjut usia tua (75 - 90 tahun) yaitu sebanyak } 13 \text { orang } \\
\text { (65,0\%), berjenis kelamin perempuan sebanyak } 14 \text { orang (70,0\%), dan } \\
\text { mempunyai riwayat penyakit hipertensi sebanyak } 17 \text { orang (85,0\%), } \\
\text { sebagian besar responden mempunyai kekuatan otot leher pada kategori } \\
\text { baik sebanyak } 12 \text { orang (60,0\%), kekuatan otot bahu pada kategori baik } \\
\text { sebanyak } 13 \text { orang (65,0\%), kekuatan otot bisep pada kategori baik } \\
\text { sebanyak } 10 \text { orang (50,0\%), kekuatan otot trisep pada kategori baik } \\
\text { sebanyak } 12 \text { orang (60,0\%), kekuatan otot kuadrisep pada kategori cukup } \\
\text { sebanyak } 12 \text { orang (60,0\%), kekuatan otot gastroknemius pada kategori } \\
\text { cukup sebanyak } 11 \text { orang (55,0\%). }\end{array}$ \\
\hline
\end{tabular}

\section{PENDAHULUAN}

World Health Organization (WHO), menyatakan bahwa pada tahun 2050, populasi dunia yang berusia 60 tahun dan lebih tua diperkirakan berjumlah 2 miliar, naik dari 900 juta pada 2015. Saat ini, 125 juta orang berusia 80 tahun atau lebih. Tahun 2050, akan ada hampir sebanyak ini
(120 juta) tinggal di China saja, dan 434 juta orang di kelompok usia ini di seluruh dunia. Tahun 2050, 80\% dari semua orang tua akan tinggal di negara berpenghasilan rendah dan menengah. Laju penuaan populasi di seluruh dunia juga meningkat secara dramatis. Prancis memiliki hampir 150 tahun untuk beradaptasi dengan perubahan dari $10 \%$ menjadi $20 \%$ dalam 
proporsi populasi yang lebih tua dari 60 tahun. Namun, tempat-tempat seperti Brasil, Cina dan India akan memiliki sedikit lebih dari 20 tahun untuk melakukan hal yang sama (Colombo et al., 2012).

Proses menua adalah peristiwa yang akan terjadi pada laki-laki dan perempuan, baik muda maupun tua. Hal tersebut dikarenakan proses menua merupakan bagian dari peristiwa siklus kehidupan manusia. Siklus kehidupan manusia dimulai dari janin dan berakhir pada tahapan lanjut usia dan kematian. Lanjut usia merupakan tahap akhir perkembangan manusia. Sehingga lansia adalah manusia dewasa yang telah mengalami proses menua tahap akhir (Ridha \& Putri, 2015).

Seiring penuaan, serat otot akan mengecil, dan massa otot berkurang. Seiring berkurangnya massa otot, kekuatan otot juga berkurang. Kekuatan muskuler mulai merosot sekitar usia 40 tahun, dengan kemunduran yang dipercepat setelah usia 60 tahun. Sekitar 10 sampai $15 \%$ kekuatan otot dapat hilang setiap minggu jika otot beristirahat sepenuhnya, dan sebanyak $5,5 \%$ dapat hilang setiap hari pada kondisi istirahat dan imobilitas sepenuhnya (Ari, 2013).

Penurunan kekuatan otot pada ekstremitas bawah pada lansia dapat menyebabkan terjadinya penurunan kemampuan mempertahankan keseimbangan tubuh pada lansia sehingga menyebabkan terjadinya resiko jatuh pada lansia dan lansia mengalami kesulitan untuk berjalan. Kesulitan dalam beraktifitas sehari-hari mengakibatkan lansia memerlukan bantuan orang lain (Kisner C Colby L, n.d.2016)

Upaya untuk mencegah terjadinya penurunan kekuatan otot pada lansia adalah dengan latihan rentang gerak range of motion (ROM). ROM bertujuan untuk mempertahankan dan meningkatkan kekuatan dan kelenturan otot, mempertahankan fungsi kardiorespirasi, menjaga fleksibilitas persendian, dan mencegah kontraktur sendi (Safa'ah,
2013).

Pemberian latihan ROM aktif dilakukan selama tiga kali seminggu dengan durasi waktu \pm 30 menit dan pengulangan gerak 8 kali sehingga akan meningkatkan skala kekuatan otot ekstremitas atas dan ekstremitas bawah (Kisner C Colby L, n.d.2016)

Hasil penelitian (Sahmad et al., 2018), tentang Pengaruh pemberian range of motion (ROM) pasif terhadap fleksibilitas sendi pada lansia di Panti Sosial Tresna Werda Minaula Kendari didapatkan bahwa ada pengaruh pemberian range of motion (ROM) pasif terhadap fleksibilitas sendi lutut, sendi mata kaki, sendi kaki pada Lansia di PSTW Minaula Kendari. Hal ini menunjukkan bahwa latihan range of motion (ROM) pasif terhadap peningkatan rentang gerak sendi pada lansia. Hal ini terlihat dari hasil penelitian yang menunjukkan bahwa rentang gerak sendi lutut, mata kaki, dan kaki lansia mengalami peningkatan.

Berdasarkan studi pendahuluan yang dilakukan di Rojinhome Kabushiki Kaisha Yoichi Yonabaru Okinawa Jepang pada tanggal 10 Desember 2019 didapatkan jumlah pasien lansia yang dirawat sebanyak 32 orang yang terdiri dari 11 orang laki-laki dan 21 orang perempuan. Lansia yang dirawat di Rojinhome Kabushiki Kaisha Yoichi Yonabaru berusia 60 - 100 tahun. Penyakit yang diderita lansia antara lain: hipertensi, stroke, hipotensi, dekubitus. Hasil observasi sebanyak 20 orang lansia mengalami gangguan keaktifan fisik. Lansia mengalami penurunan fungsi gerak sendi dan penurunan kekuatan otot. Keluhan yang paling banyak mengalami nyeri pada persendian. Keadaan ini semakin parah karena lansia kurang melakukan aktivitas olahraga karena alasan mudah lelah dan tidak dapat berdiri lama-lama.

Berdasarkan uraian latar belakang maka dapat dirumuskan permasalahan yaitu "Bagaimanakah gambaran kekuatan otot pada lansia di Rojinhome Yoichi Kokuba Yanabaru Okinawa Jepang?". 


\section{METODE PENELITIAN}

Jenis penelitian ini adalah penelitian deskriptif kuantitatif. Metode penelitian kuantitatif yang bersifat deskriptif yaitu mengidentifikasi gambaran kekuatan otot pada lansia. Tempat penelitian ini dilaksanakan di Rojinhome Yoichi Kokuba Yanabaru Okinawa Jepang.

Penelitian ini dilaksanakan sesuai dengan jadwal penelitian yaitu pada bulan Desember 2019 sampai dengan Juli 2020. Tepatnya di tanggal 26 maret 2020 mulai dilakukan pengambilan data. Teknik pengambilan sampel yang digunakan dalam penelitian ini adalah teknik non probability sampling dengan jenis quota sampling. sampel pada penelitian ini diambil dari lansia di Rojinhome Yoichi Kokuba Yonabaru Okinawa Jepang sebanyak 20 orang.

\section{HASIL PENELITIAN}

Rojinhome Kabushiki Kaisha Yoichi adalah salah satu panti lansia yang berada di Yonabaru Okinawa Jepang. Bangunan panti lansia ini berdiri dengan tiga lantai yang dihuni oleh 32 lansia di dalamnya. Bangunan lantai 1 terdapat berbagai macam ruangan seperti ruang masak, ruang untuk tempat pemandian, 5 toilet untuk perempuan, 5 toilet untuk laki-laki, ruang istirahat siang yang mencangkup 10 tempat tidur, ruang staf dan ruang bermain yang dilengkapi meja, kursi, televisi dan perlengkapan rehabilitasi untuk melatih otot, keseimbangan tubuh maupun peregangan. Sedangkan di lantai 2 dan 3 dikhususkan untuk kamar tidur dan satu ruangan yang luas untuk tempat makan bersama lansia yang berada di Rojinhome kabushiki kaisha yoichi. Di ruang makan tersebut di lengkapi 1 kulkas, televisi, 4 wastafel dimana 3 wastafel dijadikan sebagai tempat khusus lansia yang dilengkapi peralatan gosok gigi, dan 1 wastafel khusus untuk mencuci peralatan makan.

Tempat panti lansia ini menyediakan berbagai alat untuk membantu lansia berpindah tempat seperti kursi roda, kruk, walker bahkan disetiap kamar tersedia toilet portable bagi lansia yang masih bisa berpindah tempat secara mandiri. Untuk berpindah dari lantai satu ke lantai lainnya , panti lansia kabushiki kaisha yoichi menyediakan 2 lift dan dua tangga sebagai jalur evakuasi. Kondisi fisik bangunan dan kelengkapan di Rojinhome Kabushiki kaisha Yoichi Yonabaru Jepang ini tergolong baik gambar.

Penelitian ini dilaksanakan di Rojinhome Yoichi Kokuba Yanabaru Okinawa Jepang pada tanggal 26 Maret 2020. Responden dalam penelitian ini adalah lansia di Rojinhome Kabushiki Kaisha Yoichi Yonabaru Okinawa Jepang yaitu sebanyak 20 orang. Hasil penelitian dapat dijelaskan sebagai berikut:

Tabel Data Frekuensi Karakteristik Lansia di 1 Rojinhome Yoichi Kokuba Yonabaru Okinawa Jepang

\begin{tabular}{lll}
\hline Karakteristik & $\mathrm{F}$ & $\%$ \\
\hline Usia & & \\
Lanjut Usia (60 - 74 tahun) & 4 & 20,0 \\
Lanjut Usia Tua (75 - 90 & 13 & 65,0 \\
tahun) & 3 & 15,0 \\
Usia Sangat Tua (>90 tahun) & & \\
\hline Jenis Kelamin & & \\
Perempuan & 14 & 70,0 \\
Laki-Laki & 6 & 30,0 \\
Riwayat Penyakit & 17 & 85,0 \\
Hipertensi & 0 & 0,0 \\
Penyakit jantung & 0 & 0,0 \\
Diabetes Mellitus & 3 & 15,0 \\
Hiperkolesterolimia & 20 & 100,0 \\
\hline \multicolumn{1}{r}{ Total }
\end{tabular}

Berdasarkan tabel 1 dapat dijelaskan bahwa sebagian besar lansia pada kategori lanjut usia tua (75-90 tahun) sebanyak 13 orang $(65,0 \%)$, sedangkan kategori lanjut usia (60-74 tahun) sebanyak 4 orang $(20,0 \%)$ dan kategori usia sangat tua $(>90$ tahun) sebanyak 3 orang $(15,0 \%)$. Lansia sebagian besar berjenis kelamin perempuan sebanyak 14 orang $(70,0 \%)$, sedangkan lansia berjenis kelamin laki-laki sebanyak 6 orang (30,0\%). Lansia sebagian besar mempunyai riwayat penyakit hipertensi sebanyak 17 orang $(85,0 \%)$, sedangkan riwayat penyakit Hiperkolesterolimia sebanyak 3 orang $(15,0 \%)$, dan tidak ada lansia yang 
mempunyai riwayat penyakit jantung/ diabetes mellitus.

Tabe Data Frekuensi Kekuatan Otot Leher 12 Lansia di Rojinhome Yoichi Kokuba Yonabaru Okinawa Jepang

\begin{tabular}{lll}
\hline Kekuatan Otot Leher & F & $\%$ \\
\hline Tidak ada fungsi & 0 & 0,0 \\
Buruk & 0 & 0,0 \\
Kurang & 1 & 5,0 \\
Cukup & 2 & 10,0 \\
Baik & 12 & 60,0 \\
Normal & 5 & 25,0 \\
\hline Total & 20 & 100,0 \\
\hline
\end{tabular}

Berdasarkan tabel 2 dapat dijelaskan bahwa sebagian besar lansia mempunyai kekuatan otot leher pada kategori baik sebanyak 12 orang $(60,0 \%)$, sedangkan kekuatan otot leher pada kategori normal sebanyak 5 orang $(25,0 \%)$, kategori cukup sebanyak 2 orang $(10,0 \%)$, dan kategori kurang sebanyak 1 orang $(5,0 \%)$.

Tabe Data Frekuensi Kekuatan Otot Bahu 13 Lansia di Rojinhome Yoichi Kokuba Yonabaru Okinawa Jepang

\begin{tabular}{lll}
\hline Kekuatan Otot Bahu & F & $\%$ \\
\hline Tidak ada fungsi & 0 & 0,0 \\
Buruk & 0 & 0,0 \\
Kurang & 2 & 10,0 \\
Cukup & 4 & 20,0 \\
Baik & 13 & 65,0 \\
Normal & 1 & 5,0 \\
\hline Total & 20 & 100,0 \\
\hline
\end{tabular}

Berdasarkan tabel 3 dapat dijelaskan bahwa sebagian besar lansia mempunyai kekuatan otot bahu pada kategori baik sebanyak 13 orang $(65,0 \%)$, sedangkan kekuatan otot bahu pada kategori cukup sebanyak 4 orang $(20,0 \%)$, kategori kurang sebanyak 4 orang $(20,0 \%)$,dan kategori normal sebanyak 1 orang $(5,0 \%)$.

Tabel Data Frekuensi Kekuatan Otot Siku 4 (Bisep) Lansia di Rojinhome Yoichi Kokuba Yonabaru Okinawa Jepang

\begin{tabular}{lll}
\hline Kekuatan Otot Siku (Bisep) & F & $\%$ \\
\hline Tidak ada fungsi & 0 & 0,0 \\
Buruk & 0 & 0,0 \\
Kurang & 1 & 5,0 \\
Cukup & 9 & 45,0 \\
Baik & 10 & 50,0 \\
Normal & 0 & 0,0 \\
\hline Total & 20 & 100,0 \\
\hline
\end{tabular}

Berdasarkan tabel 4 dapat dijelaskan bahwa sebagian besar lansia mempunyai kekuatan otot siku (Bisep) pada kategori baik sebanyak 10 orang $(50,0 \%)$, sedangkan kekuatan otot siku (Bisep) pada kategori cukup sebanyak 9 orang $(10,0 \%)$, dan kategori kurang sebanyak 1 orang $(5,0 \%)$.

Tabel Data Frekuensi Kekuatan Otot Siku 5 (Trisep) Lansia di Rojinhome Yoichi Kokuba Yonabaru Okinawa Jepang

\begin{tabular}{lll}
\hline Kekuatan Otot Siku (Trisep) & F & $\%$ \\
\hline Tidak ada fungsi & 0 & 0,0 \\
Buruk & 0 & 0,0 \\
Kurang & 1 & 5,0 \\
Cukup & 2 & 10,0 \\
Baik & 12 & 60,0 \\
Normal & 5 & 25,0 \\
\hline \multicolumn{1}{c}{ Total } & 20 & 100,0 \\
\hline
\end{tabular}

Berdasarkan tabel 5 dapat dijelaskan bahwa sebagian besar lansia mempunyai kekuatan otot siku (Trisep) pada kategori baik sebanyak 12 orang $(60,0 \%)$, sedangkan kekuatan otot siku (Trisep) pada kategori normal sebanyak 5 orang $(25,0 \%)$, kategori cukup sebanyak 2 orang $(10,0 \%)$, dan kategori kurang sebanyak 1 orang $(5,0 \%)$.

Tabel Data Frekuensi Kekuatan Otot Pinggang 6 (Kuadrisep) Lansia di Rojinhome Yoichi Kokuba Yonabaru Okinawa Jepang

\begin{tabular}{|c|c|c|c|}
\hline $\begin{array}{ll}\text { Kekuatan } & \text { Otot } \\
\text { (Kuadrisep) } & \end{array}$ & Pinggang & $\mathrm{F}$ & $\%$ \\
\hline Tidak ada fungsi & & 0 & 0,0 \\
\hline Buruk & & 1 & 5,0 \\
\hline Kurang & & 4 & 20,0 \\
\hline Cukup & & 12 & 60,0 \\
\hline Baik & & 3 & 15,0 \\
\hline Normal & & 0 & 0,0 \\
\hline Total & & 20 & 100,0 \\
\hline
\end{tabular}

Berdasarkan tabel 6 dapat dijelaskan bahwa sebagian besar lansia mempunyai kekuatan otot pinggang (Kuadrisep) pada kategori cukup sebanyak 12 orang (60,0\%), sedangkan kekuatan otot pinggang (Kuadrisep) pada kategori kurang sebanyak 4 orang $(20,0 \%)$, dan kategori baik sebanyak 3 orang $(15,0 \%)$.

Tabel Data Frekuensi Kekuatan Otot Pinggang $7 \quad$ (Gastroknemius) Lansia di Rojinhome Yoichi Kokuba Yonabaru Okinawa Jepang

\begin{tabular}{|c|c|c|c|}
\hline $\begin{array}{ll}\begin{array}{l}\text { Kekuatan } \\
\text { (Gastroknemius) }\end{array} & \text { Otot } \\
\end{array}$ & Pinggang & $\mathrm{F}$ & $\%$ \\
\hline Tidak ada fungsi & & 0 & 0,0 \\
\hline Buruk & & 1 & 5,0 \\
\hline Kurang & & 5 & 25,0 \\
\hline Cukup & & 11 & 55,0 \\
\hline Baik & & 3 & 15,0 \\
\hline Normal & & 0 & 0,0 \\
\hline Total & & 20 & 100,0 \\
\hline
\end{tabular}


Berdasarkan tabel 7 dapat dijelaskan bahwa sebagian besar lansia mempunyai kekuatan otot pinggang (Gastroknemius) pada kategori cukup sebanyak 11 orang $(55,0 \%)$, sedangkan kekuatan otot pinggang (Gastroknemius) pada kategori kurang sebanyak 5 orang $(25,0 \%)$, kategori baik sebanyak 3 orang $(15,0 \%)$, dan kategori buruk sebanyak 1 orang $(5,0 \%)$.

\section{PEMBAHASAN}

\section{Usia}

Hasil penelitian didapatkan bahwa sebagian besar lansia pada kategori lanjut usia tua (75-90 tahun). Hal ini menunjukkan bahwa bertambahnya usia lansia terdapat penurunan fisik, perubahan mental, (penampilan, persepsi, dan ketrampilan psikomotor berkurang). Asumsi peneliti sesuai fakta dilapangan didapatkan bahwa lansia yang berada di Rojinhome Kabushiki Kaisha Yoichi Yonabaru Okinawa Jepang masih bisa melakukan aktivitas sehari-hari dengan baik karena, kegiatan yang dibuat oleh pihak panti seperti latihan rentang gerak (ROM) sesuai anjuran pihak panti dilaksanakan secara konstan dengan bantuan para staf di Rojinhome Yoichi untuk mengarahkan, melatih dan mendampingi lansia dalam melakukan kegiatan latihan rentang gerak (ROM) sehingga dapat meningkatkan fungsi muskuloskeletal pada lansia.

Kekuatan muskuler mulai merosot sekitar usia 40 tahun, dengan kemunduran yang dipercepat setelah usia 60 tahun. Penurunan penggunaan sistem muskuler adalah penyebab utama untuk kehilangan kekuatan otot. Seiring penuaan, serat otot akan mengecil, dan massa otot berkurang. Seiring berkurangnya massa otot, kekuatan otot juga berkurang (Krismiati, Murti, Putriyanti, Berlina, Iswanti Ningsi, 2019).

Hasil penelitian ( Gabriella et al., 2019), tentang hubungan penurunan kekuatan otot dan massa otot dengan proses penuaan pada individu lanjut usia yang sehat secara fisik menyatakan bahwa penurunan massa otot dan kekuatan otot pada individu lanjut usia menjadi masalah aditif dengan prevalensi yang tinggi. Menilai kehilangan massa otot dan kekuatan otot yang berhubungan dengan usia serta menentukan mekanisme terjadinya atrofi otot pada proses penuaan, struktur otot dan komposisi serat otot telah dilakukan, dengan menggunakan teknik invasif dan noninvasif. Penurunan ukuran volume secara bertahap seiring bertambahnya usia, disertai penggantian oleh jaringan lemak dan ikat.

Penurunan kekuatan otot merupakan salah satu perubahan yang nyata dari proses penuaan. Menurunnya kekuatan otot disebabkan oleh banyak faktor. Faktor penyebab yang utama yaitu penurunan massa otot. Penurunan kekuatan otot ini dimulai pada umur 40 tahun dan prosesnya akan semakin cepat pada usia setelah usia 75 tahun. Para peneliti dari Columbia University Medical Center menemukan bahwa menurunnya kekuatan otot pada penuaan terjadi akibat kebocoran kalsium dari kelompok protein dalam sel otot yang disebut ryanodine yang kemudian memicu terjadinya rangkaian kejadian yang membatasi kontraksi serabut otot. Dengan berkurangnya kalsium yang tersedia, kontraksi otot melemah(Kisner C Colby L, n.d. 2016)

\section{Jenis Kelamin}

Hasil penelitian didapatkan bahwa sebagian besar lansia di Rojinhome Yoichi Kokuba Yonabaru Okinawa Jepang berjenis kelamin perempuan. Hal ini menunjukkan bahwa jenis kelamin adalah faktor yang berkaitan dengan ketahanan otot antara perempuan dan laki-laki. Terkait hal itu, jenis kelamin berkaitan erat dengan keluhan Musculoskeletal Disorders hal ini dikarenakan secara fisiologis kemampuan otot laki-laki lebih kuat dibanding kemampuan otot perempuan.

Beberapa ahli berbeda pendapat mengenai pengaruh perbedaan jenis kelamin dengan keluhan musculoskeletal, akan tetapi pada beberapa penelitian mendapatkan bahwa jenis kelamin menunjukan pengaruh yang signifikan 
terhadap risiko keluhan otot. Kekuatan/kemampuan otot dimiliki perempuan hanya sekitar dua per tiga dari kekuatan otot laki-laki, sehingga kapasitas otot perempuan lebih kecil jika dibandingkan dengan kapasitas otot lakilaki (Tarwaka, 2014).

Hal yang perlu dimengerti adalah sikap umum yang ditemukan pada hampir setiap lanjut usia, yakni keinginan berumur panjang, tenaganya sedapat mungkin dihemat. Individu tetap mengharapkan tetap diberi peranan dalam masyarakat, ingin mempertahankan hak dan harkatnya serta ingin tetap berwibawa. Faktor-faktor yang mempengaruhi perubahan mental yaitu perubahan fisik khususnya organ perasa, kesehatan pada umunya lansia gampang sakit, tingkat pendidikan, keturunan dan lingkungan(Nisa \& Lisiswanti, 2016)

\section{Riwayat Penyakit}

Hasil penelitian didapatkan bahwa sebagian besar lansia mempunyai riwayat penyakit hipertensi. Hal ini menunjukkan bahwa adanya berbagai penyakit kronis seperti jantung, metabolik, keganasan maupun suatu keadaan multipatologi dan polifarmasi sangat berkaitan dengan rendahnya kualitas hidup lansia.

Penelitian yang di lakukan (Baert et al., 2017), mengatakan bahwa lansia sebagai populasi berisiko ini memiliki tiga karakteristik risiko kesehatan yaitu, risiko biologi termasuk risiko terkait usia, risiko sosial dan lingkungan serta risiko perilaku atau gaya hidup. Risiko biologi termasuk risiko terkait usia pada lanjut usia yaitu terjadinya berbagai penurunan fungsi biologi akibat proses menua. Risiko sosial dan lingkungan pada lanjut usia yaitu adanya lingkungan yang memicu stres. Aspek ekonomi pada lansia yaitu penurunan pendapatan akibat pensiun. Risiko perilaku atau gaya hidup seperti pola kebiasaan kurangnya aktivitas fisik seperti senam, latihan rentang gerak, berolahraga dan kegiatan lainnya yang termasuk dalam mobilisasi) dan konsumsi makanan yang tidak sehat dapat memicu terjadinya penyakit dan kematian.

Penelitian yang dilakukan (Nisa \& Lisiswanti, 2016), menyatakan bahwa individu yang mengidap diabetes memiliki risiko yang lebih besar dalam pengembangan penyakit demensia dan gangguan kognitif. Diabetes yang berkaitan dengan disfungsi kognitif ini, bahkan dipertimbangkan untuk dianggap sebagai jenis lain komplikasi diabetes. Dalam penelitian ini, partisipan yang memiliki riwayat diabetes memiliki skor yang cenderung tinggi untuk memori jangka pendek, namun skor yang cenderung rendah pada memori jangka panjang.

Hal ini sejalan dengan pernyataan (Ishak \& Alvina, 2019), yang menyatakan bahwa diabetes berhubungan dengan fungsi kognitif yang rendah, khususnya dalam fungsi memori jangka panjang, tetapi tidak berkaitan dengan fungsi memori jangka pendek dan kefasihan berbahasa.

Penyakit hipertensi juga berkaitan dengan fungsi kognitif seseorang. Adanya perubahan struktur dan aliran darah otak pada proses penuaan, kemungkinan menyebabkan disfungsi pada serebrovaskular dan dapat memengaruhi gangguan pada fungsi kognitif maupun perilaku seseorang. Penelitian yang dilakukan (Berawi \& Agverianti, 2017), menyebutkan bahwa hipertensi yang terkait dengan penurunan kognitif seseorang merupakan konsekuensi dari reorganisasi fungsi aliran darah dan kerusakan pembuluh darah otak yang saling memengaruhi.

Perawatan pada lansia harus memperhatikan kesehatan obyektif, kebutuhan, kejadian-kejadian yang dialami klien lanjut usia semasa hidupnya, perubahan fisik pada organ tubuh, tingkat kesehatan yang masih biasa di capai dan dikembangkan dan penyakit yang dapat dicegah atau ditekan progresifitasnya.

\section{Kekuatan Otot}


Hasil penelitian didapatkan bahwa sebagian besar lansia mempunyai kekuatan otot leher, bahu, siku (Bisep dan Trisep) pada kategori baik, dan sebagian besar lansia mempunyai kekuatan otot pinggang (Kuadrisep dan Gastroknemius) pada kategori cukup. Hal ini menunjukkan bahwa latihan kegiatan rentang gerak range of motion (ROM) secara konstan yang dilakukan di Rojinhome Yoichi Kokuba Yonabaru Okinawa Jepang setiap pagi dan sore selama 10 menit dapat meningkatkan kekuatan otot pada lansia. Kegiatan yang juga sering dilakukan oleh lansia di Rojinhome Yoichi Kokuba Yonabaru Okinawa Jepang seperti senam, latihan rentang gerak ROM pasif maupun ROM aktif yang didampingi oleh para staf dapat membantu lansia untuk mempertahankan keseimbangan tubuh dan melatih kekuatan otot pada lansia. Kondisi menua yang dialami lansia menjadikan lansia mengalami berbagai penurunan fungsi sistem tubuh secara keseluruhan sehingga mengakibatkan lansia memiliki masalah dalam memenuhi kebutuhan sehari-harinya. Spesifik yang terjadi pada sistem muskuloskeletal yaitu sendi juga terjadi perubahan. Secara anatomis, sendi gerak mengalami penipisan hingga hilangnya lapis kartilago atau tulang rawan, penurunan jumlah cairan sendi, serta longgarnya soket sendi. Hal ini menyebabkan fleksibilitas sendi menurun sehingga pergerakan menjadi terbatas dan mobilisasi pun menjadi sulit (Lilik Pranata, Dheni Koernawan, 2019).

Kekakuan juga dapat menyebabkan menurunnya lingkup gerak sendi lutut, mata kaki, dan kaki dan menambah nyeri sendi karena berfungsi sebagai penopang tubuh maka mempunyai struktur ligamentum yang lebih kuat dan banyak dari pada sendi lainnya walaupun keduanya sama-sama. Hal ini juga akan mempengaruhi kemungkinan terjadinya kekakuan yang lebih besar pada sendi lutut, kaki, dan mata kaki tersebut. Adanya keterbatasan pergerakan dan berkurangnya pemakaian sendi dapat memperparah kondisi tersebut. Penurunan kemampuan muskuloskeletal dapat menurunkan aktivitas fisik (physical activity) dan latihan (exercise), sehingga akan mempengaruhi lansia dalam melakukan aktivitas kehidupan sehari-hari (Activity Daily Living atau ADL) sehingga quality oflife menurun.

Besar peningkatan kekuatan otot dipengaruhi oleh jenis latihan, intensitas latihan, dan usia. Kontraksi isotonik menyebabkan kekuatan otot meningkat pada seluruh lingkup gerak sendi. Pemberian latihan penguatan dengan intensitas ringan sampai sedang sudah dapat meningkatkan kekuatan otot secara bermakna pada usia lanjut. Semakin sering latihan dilakukan maka persentase peningkatan kekuatan otot akan semakin besar (Widiastuti et al., n.d, 2011).

Seperti yang dikemukakan (Ishak \& Alvina, 2019), dengan pemeliharaan kekuatan otot dan fleksibilitas sendi, latihan range of motion (ROM) bisa meningkatkan dan mempertahankan kekuatan otot dan fleksibilitas sendi karena dari 10 sampai $15 \%$ kekuatan otot dapat hilang setiap minggu jika otot beristirahat sepenuhnya,dan sebanyak $5,5 \%$ dapat hilang setiap hari pada kondisi istirahat dan imobilitas sepenuhnya.

Hasil penelitian (Ridha \& Putri, 2015), tentang Pengaruh latihan range of motion (ROM) aktif terhadap kekuatan otot ekstremitas bawah pada lansia dengan osteoarthritis di Wilayah Kerja Puskesmas Koni Kota Jambi menunjukkan efek latihan range of motion aktif pada peningkatan kekuatan otot ekstremitas bawah pada lansia dengan osteoarthritis di Puskesmas Koni Jambi. Analisis bivariat menggunakan Paired T-Test diperoleh nilai $\mathrm{p}=0,000$ dan kemudian nilai $\mathrm{p}<0,05$.

Hasil penelitian lain oleh (Kusumowardani \& Wahyuni, 2017), tentang pengaruh latihan ROM aktif terhadap keaktifan fisik pada lansia di Dusun Karang Templek Desa Andongsari Kecamatan Ambulu Kabupaten Jember didapatkan bahwa ada pengaruh latihan 
ROM aktif terhadap keaktifan fisik. Latihan ROM aktif pada kelompok lansia, sebagai bentuk pemberian latihan untuk mengembalikan fungsi geraknya secara normal. Pemberian latihan ROM aktif dilakukan selama 30 menit selama satu minggu dua kali untuk meningkatkan kekuatan otot dan memberi kesehatan fisik pada lansia.

Sejalan dengan penelitian (Filantip, 2015), tentang pengaruh latihan range of motion aktif terhadap kelentukan sendi ektremitas bawah dan gerak motorik pada lansia di Unit Pelayanan Sosial Wening Wardoyo Ungaran didapatkan bahwa range of motion memiliki pengaruh terhadap rentang gerak responden bila dilakukan dengan frekuensi dua kali sehari dalam enam hari dan dengan waktu 10-15 menit dalam sekali latihan. Latihan dua kali sehari dalam 6 hari dengan waktu 1015 menit akan berpengaruh terhadap rentang gerak lansia.

Peningkatan rentang gerak sendi dapat mengaktifkan gerak volunter yaitu gerak volunter terjadi adanya transfer impuls elektrik dan girus presentralis ke kordaspinalis melalui nurotransmiter yang mencapai otot dan menstimulasi otot sehingga menyebabkan pergerakan. Untuk menimbulkan gerakan disadari kearah normal, tahapan pertama kali yang dilakukan adalah memperbaiki tonus otot maupun refleks tendon kearah normal yaitu dengan cara memberikan stimulus terhadap otot maupun proprioceptor dipersendian yaitu melalui approksimasi (Lin et al., 2019)

\section{SIMPULAN DAN SARAN}

Lansia di Rojinhome Kabushiki Kaisha Yoichi Yonabaru Okinawa Jepang sebagian besar pada kategori lanjut usia tua (75 - 90 tahun) yaitu sebanyak 13 orang $(65,0 \%)$, berjenis kelamin perempuan sebanyak 14 orang $(70,0 \%)$, dan mempunyai riwayat penyakit hipertensi sebanyak 17 orang (85,0\%). Lansia di Rojinhome Kabushiki Kaisha Yoichi Yonabaru Okinawa Jepang sebagian besar mempunyai kekuatan otot leher pada kategori baik sebanyak 12 orang $(60,0 \%)$, kekuatan otot bahu pada kategori baik sebanyak 13 orang $(65,0 \%)$, kekuatan otot siku (Bisep) pada kategori baik sebanyak 10 orang $(50,0 \%)$, kekuatan otot siku (Trisep) pada kategori baik sebanyak 12 orang $(60,0 \%)$, kekuatan otot pinggang (Kuadrisep) pada kategori cukup sebanyak 12 orang $(60,0 \%)$, kekuatan otot pinggang (Gastroknemius) pada kategori cukup sebanyak 11 orang $(55,0 \%)$.

Lansia diharapkan untuk mampu mempertahankan dan meningkatkan kekuatan dan kelenturan otot, mempertahankan fungsi kardiorespirasi, menjaga fleksibilitas persendian, dan mencegah kontraktur sendi agar dapat beraktifitas dengan baik, senantiasa menjaga kesehatan dan aktif mengikuti kegiatan-kegiatan serta melakukan latihan gerak sendi / ROM secara mandiri dalam pemenuhan activity daily living (ADL).

\section{DAFTAR PUSTAKA}

[1] Ari, R. A. (2013). Naskah publikasi koping lanjut usia yang diserahkan keluarga ke panti wredha dharma bhakti surakarta. 1-15.

[2] Baert, V., Gorus, E., Mets, T., Geerts, C., Bautmans, I., Baumgart, M., Snyder, H. M., Carrillo, M. C., Fazio, S., Kim, H., Johns, H., Brown, B. M., Peiffer, J. J., Sohrabi, H. R., Mondal, A., Gupta, V. B., Rainey-Smith, S. R., Taddei, K., Burnham, S., ... Kremen, W. S. (2017), 済無No Title No Title. Repositori Uinjkt, 6(1), 1-8. https://doi.org/10.1016/j.jamda.2008.0 2.007

[3] Berawi, K. N., \& Agverianti, T. (2017). Efek Aktivitas Fisik pada Proses Pembentukan Radikal Bebas sebagai Faktor Risiko Aterosklerosis. Jurnal Majority, 6(2), 86-91. http://juke.kedokteran.unila.ac.id/inde x.php/majority/article/view/1019

[4] Colombo, P. J., Crawley, M. E., East, B. S., \& Hill, A. R. (2012). Aging and 
the Brain. Encyclopedia of Human Behavior: Second Edition, 53-59. https://doi.org/10.1016/B978-0-12375000-6.00006-9

[5] Filantip, A. (2015). Pengaruh Latihan Range of Motion (ROM) Aktif Terhadap Kelentukan Sendi Ektremitas Bawah dan Gerak Motorik Pada Lansia di Unit Pelayanan Sosial Wening Wardoyo Ungaran. In Ojs.Fdk.Ac.Id.

https://ojs.fdk.ac.id/index.php/Nursing /index

[6] Ishak, M., \& Alvina, A. (2019). Pengaruh yoga terhadap memori jangka pendek pada dewasa muda. Jurnal Biomedika Dan Kesehatan, 2(3), 117-123. https://doi.org/10.18051/jbiomedkes.2 019.v2.117-123

[7] Kisner C Colby L. (n.d.).

[8] Krismiati, Murti, Putriyanti, Berlina, Iswanti Ningsi, E. (2019). Peningkatan kualitas hidup lansia melalui penerapan pola hidup sehat di dusun Gondang dan dusun Donoasih Donokerto Turi Sleman. Jurnal Pengabdian Masyarakat Karya Husada, 1(2), 68-76.

[9] Kusumowardani, A., \& Wahyuni, E. S. (2017). PENGARUH LATIHPengaruh Latihan Fisik Terhadap Kemampuan Kognitif Lansia Di Desa Ngesrep Kecamatan Ngemplak Kabupaten BoyolaliAN FISIK TERHADAP KEMAMPUAN KOGNITIF LANSIA DI DESA NGESREP KECAMATAN NGEMPLAK KABUPATEN BOYOLALI. Interest: Jurnal Ilmu Kesehatan, 6(2), 168-178. https://doi.org/10.37341/interest.v6i2. 98

[10] Lilik Pranata, Dheni Koernawan, N. E. D. (2019). Efektifitas Rom Terhadap Gerak Rentang Sendi Lansia. Proceeding Seminar Nasional Keperawatan, 5(1), 110-117.
[11] Lin, S., Yang, Y., Qi, Q., Wei, L., Jing, N., Jie, Z., Xia, L., \& Shifu, X. (2019). The beneficial effect of physical exercise on cognitive function in a non-dementia aging Chinese population. Frontiers in Aging Neuroscience, 11(AUG), 1-8. https://doi.org/10.3389/fnagi.2019.002 38

[12] Nisa, K. M., \& Lisiswanti, R. (2016). Faktor Risiko Demensia Alzheimer. Majority, 5(4), 86-87. http://juke.kedokteran.unila.ac.id/inde x.php/majority/article/view/890

[13] Pada, P., Lanjut, I., Yang, U., \& Secara, S. (2019). $1 *, 2$ 2. 5(1), 1-5.

[14] Ridha, M. R., \& Putri, M. E. (2015). Pengaruh latihan Range Of Motion(ROM) aktif terhadap kekuatan otot ekstremitas bawah pada lansia dengan osteoarthritis di wilayah kerja puskesmas koni kota jambi. Jurnal Akademika Baiturrahim, 4(2), 45-52.

[15] Safa'ah, N. (2013). Pengaruh Latihan Range of Motion terhadap Peningkatan Kekuatan Otot Lanjut Usia di UPT Pelayanan Sosial Lanjut Usia ( Pasuruan ) Kec . Babat Kab Lamongan. Jurnal Sains Medical, 5(2), 62-65. https://www.kopertis7.go.id/uploadjur nal/Nurus_Safaah_stikes_nu_tuban.pd $\mathrm{f}$

[16] Sahmad, S., Yunus, R., \& Sarmawan, A. (2018). Pengaruh Pemberian Range of Motion (Rom) Pasif Terhadap Fleksibilitas Sendi Pada Lansia Di Panti Sosial Tresna Werda Minaula Kendari. Jurnal Kesehatan Manarang, 2(2), 89. https://doi.org/10.33490/jkm.v2i2.21

[17] Widiastuti, A., Wibawa, A., Handari, I., \& Sri, S. (n.d.). Pengaruh senam lansia terhadap peningkatan kebugaran fisik pada kelompok lansia perempuan di desa Dauh Puri Kauh Denpasar Barat. 5, 24-27. 